\title{
Empowerment og disempowerment? To historier om hjemmehjælperfeltet
}

Af Hanne Marlene Dahl

Hvordan skal udviklingen af en omsorgspolitik på hjemmehjalperfeltet tolkes? Som empowerment eller som disempowerment? Ev italesettelse bedre end tavshed? Diskursanalysen af professionalisme, omsorg og kon diskuterer udviklingen af omsorgsarbejdet $i$ perioden 1943 - 1995

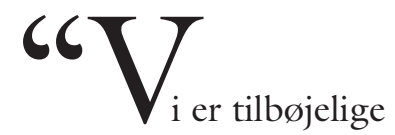

til at tro, at de, der bliver hørt, har magt" (Knudsen 1990, 48)

Sådan skrev den danske antropolog Anne Knudsen i en indledning til en artikel om magt og tavshed for at beskrive den fremherskende opfattelse af magt. Jeg har valgt sætningen, da jeg bl.a. vil tematisere forholdet mellem magt og tavshed. Men sætningen mangler noget. Derfor fristes jeg til at omformulere sætningen til: "Vi er tilbøjelige til at tro, at de, der har talt og bliver hørt, har magt". Det, at tale og blive lyttet til, associeres ofte med magt - magt til at fă tilslutning til noget, og gennemføre det. Feminister har eksplicit eller implicit søgt at få omsorgsarbejdet synliggjort ved, at det hidtil skjulte arbejde blev synligt via bl.a. videnskabelige beskrivelser (Wærness 1982). Opfattelsen var og er, at kun ved en videnskabelig og/eller politisk italesættelse kunne omsorgsarbejdet blive en del af det offentlige politiske rum, og dermed, potenti- 
elt set, underlagt en højere grad af retfærdighed. Men italesættelse og tale kan også være et tveægget sværd. Både for udøverne af omsorgsarbejdet i statslige institutioner og for feminister.

I denne artikel vil jeg beskrive skabelsen af et policy-felt for omsorgsmæssige kvalifikationer, feltets udvikling over tid og fortolkningen af denne udvikling. Jeg vil sætte tolkningen i centrum ved at beskrive og diskutere to fortolkninger af udviklingen på et omsorgsmæssigt område ud fra et feministisk perspektiv. En historie om empowerment og en anden historie om disempowerment.

I den ene historie fokuseres der på udviklingen fra tavshed til tale eksemplificeret ved en italesættelse af omsorgsmæssige kvalifikationer. Det vil sige det, at der bliver talt om omsorg og nødvendige omsorgsmæssige kvalifikationer fremfor, at de er henlagt til tavshed. ${ }^{l} \mathrm{Og}$ en anden historie, der fortolker den selvsamme udvikling i et mere negativt lys. I denne mere negative tolkning problematiseres den positive opfattelse af fremkomsten af en 'omsorgspolitik' som den norske politolog Hege Skjeie har advokeret for (1992). ${ }^{2}$ Ved at fortælle to historier argumenterer jeg indirekte for velfærdsstatens ambivalens, idet de to historier afspejler henholdsvis en positiv og negativ opfattelse af velfærdsstatens omsorgsudøvelse ud fra et feministisk perspektiv. ${ }^{3}$ Ambivalensen vedrører ikke brugerne, men omsorgsfagets udøvere. Og da de udgør 90-95\% kvinder, stiller denne udvikling feminister overfor et vanskeligt dilemma.

Som case har jeg valgt omsorgen for $\mathfrak{x l}$ dre i eget hjem ved hjemmehjælpen/socialog sundhedshjælpen da det typisk er et forsømt felt. ${ }^{4}$ Den analyserede periode er 1943-95. Perioden er afgrænset ved et selvgrænsningsprincip og ved pragmatiske overvejelser. Således afgrænser materialet selv feltet til 1943, mens afgrænsningen opadtil er bestemt af tidspunktet for starten på indsamlingen af materialet (Dahl 2000, 139-140). Materialet består af betænknin- ger, redegørelser, rapporter, love, cirkulærer, skrivelser, vejledninger (herunder undervisningsvejledninger) o.lign. Metoden er diskursanalytisk, idet jeg fokuserer på mening, ambivalens og tavshed (Dahl 2000, 23, 112-160).

I det følgende vil jeg først redegøre for min tilgang, dernæst beskrive kriterierne for henholdsvis empowerment og disempowerment for derefter, at beskrive to forskellige fortolkninger af diskursens udvikling. Endelig vil jeg konkludere på analysen og beskrive et dilemma for feminister som min analyse afslører.

\section{DiskURS, MAGT OG TAVSHED}

Artiklen handler om hvordan omsorg er italesat indenfor det som jeg har kaldt 'magtens sprog'. 5 Med 'magtens sprog' forstår jeg den politisk-administrative diskurs, det vil sige den horisont, som politikere, embedsmænd- og kvinder, samt eksperter ser verden igennem. En diskurs skal forstås som en forståelses- og mulighedshorisont. Det vil sige som en horisont, der afgrænser og skitserer, hvad der er muligt, hvad der kan siges og gøres, samt hvilke positioner der legitimt kan indtages (Dahl 2000, 12, 129-131).

Når jeg anvender begrebet 'magtens sprog' i ental betyder det ikke, at der kun er et sprog. 'Magtens sprog' er i stedet at forstå som et felt, hvor konkurrerende diskurser kæmper om magten, hegemonien, om man vil. 6 Der er således flere diskurser i den ovenfra-og-ned diskurs som den politisk-administrative diskurs udgør på et givet tidspunkt. Denne diskurs er valgt som studieobjekt, da jeg har som præmis, at de forestillingsrum, som diskursen indeholder, får betydning for opfattelse af hvad de omsorgsmæssige kvalifikationer består af og dermed på længere sigt på de politiske, administrative ledere og fagets udøvere ude omkring i kommunerne.

Diskursens forestillingsrum kan også begribes som en sproglig værktøjskasse, der 
giver nogle redskaber til at forstå og forholde sig til den sociale virkelighed i kommunerne. Diskurser handler både om grænser for mening og det mulige. Dermed handler magt også om, hvilke tilgængelige subjektpositioner som personer med hovedsageligt 'kvindeligt kropstegn' kan identificere sig med (Dahl 2000, 15).7

Fokus for de to forskellige tolkninger af udviklingen på feltet er indirekte, at problematisere den franske psykolog og filosof Michel Foucaults værdimæssige relativisme (1978). ${ }^{8}$ En relativisme, hvor han argumenterer for, at skiftet fra tavshed til italesættelse ikke er en frisættelse, men blot en ny regulering af subjektet. Eller med andre ord påstår Foucault, at skiftet blot er en anden relation mellem det sagte og ikke sagte. Formålet med artiklen er, at vurdere italesættelsen og dens effekter ud fra et andet perspektiv, nemlig et feministisk kvinde- og kønsperspektiv.

Teoretisk er jeg inspireret af den postmoderne feminisme repræsenteret ved bl.a. den amerikanske politolog Nancy Fraser (1997) og den danske psykolog Dorte Marie Søndergaard (1994). Men jeg er også inspireret af den argentinsk-britiske politolog Ernesto Laclau (1985) og af systemteori repræsenteret ved den engelske sociolog Anthony Giddens (1979). En diskursanalyse er mulig at kombinere med teorier om eksistensen af et kønssystem, hvilket jeg har uddybet andetsteds (Dahl 1994 og 2000, 68-81). Jeg vil nu eksplicitere begreberne 'empowerment' og 'disempowerment' på feltet for hjemmehjælp.

\section{EMPOWERMENT, DISEMPOWERMENT OG DISKURSANALYSE}

Jeg vil forstå empowerment og disempowerment i en relativ bred forstand. Empowerment skal generelt forstås som en mægtiggørende udvikling i diskursen, mens disempowerment generelt er at forstå som et decideret tilbageslag i den diskursive udvikling. Begreberne anvendes for at evaluere den diskursive udvikling ud fra et feministisk kvinde- og kønsperspektiv.

Den amerikanske politolog Kathy Ferguson definerer empowerment som en fælles handling, hvor der skabes nye muligheder. Dermed bliver den karakteristisk for en særlig social- og politisk proces og som et bestemt resultat, hvor der skabes nye muligheder for kvinder (Ferguson 1987, 221). Jeg vil dog ikke kræve en fælles proces og/eller handling som en forudsætning for at kunne identificere en mægtiggørelse. I stedet vil jeg definere empowerment som en individuel og/eller kollektiv identifikationsog handlingsmulighed, hvor en ny diskurs angiver en udvidet forståelses- og mulighedshorisont for subjektivitet eller hidtil undertrykte værdier. Det betyder, flere og/eller bedre mulige subjektpositioner end tidligere og/eller diskursens brud med nogle sædvanlige hierarkier.

Men kriteriet for empowerment må præciseres i forhold til, hvilken slags diskurser der analyseres. Jeg vil analysere kønnede diskurser, det vil sige diskurser, der ikke eksplicit italesætter køn, men som meningsfuldt kan analyseres ud fra et kønsperspektiv for eventuelt at identificere sproglige dikotomier og valoriseringer, forstået som hierarkier i diskurserne (Dahl 2000, 135136). Mere præcist analyserer jeg på den del af feltet for hjemmehjælp, hvor den politisk-administrative diskurs italesætter omsorgsmæssige kvalifikationer.

I forlængelse af Skjeies positive evaluering af skabelsen af omsorgspolitik er det oplagt, at vurdere en italesættelse i den politisk-administrative diskurs som empowerment. Jeg vil tentativt evaluere en artikulation som værende bedre end tavshed. Italesættelse af en omsorgspolitik vil, potentielt set, indebære en øget synlighed og dermed kunne skabe et rum for debat og tale om omsorgsmæssige kvalifikationer og deres eventuelle sammenhæn med omsorgsmæssige behov. Et rum for tale og modstand samt et rum for visioner.

Samtidig vil jeg opstille to konkrete kri- 
terier nemlig, hvorvidt der udtrykkes en professionsdiskurs og hvorvidt kundskabsbasen udvides. Eksistensen af en professionsdiskurs vil blive fortolket som empowerment, da en sådan diskurs vil tillægge status til erhvervet. På samme måde vil en bredere kundskabs base blive fortolket som en mægtiggørelse. Det skyldes, at en italesættelse af hidtil udgrænsede kundskaber problematiserer den hidtidige prioritering af teoretiske (forstået som generalisérbare) kundskaber over mere kropsligt og praktiske kundskaber.

Jeg har valgt, at definere disempowerment som et tilbageslag. Det må konkret betyde, at en ny diskurs tilbyder færre og/eller dårligere subjektpositioner for kvinder, og/eller at omsorgsmæssige kundskaber ikke anerkendes eller måske endog tages for givet. Dette ville være tilfældet, hvis der optrådte en reduceret italesættelse af omsorgsmæssige kvalifikationer, eller ligefrem tavshed, og/eller hvis diskursen vendte tilbage til nogle tidligere overvundne dikotomier. Et tilbageslag ville således kunne identificeres i færre, eller mere snævert afgrænsede subjektpositioner for kvinder. Det kunne eksempelvis være positioner med en øget og mere intens styring af hjemmehjælpernes kvalifikationer via diskursen.

Jeg vil nu fortælle en af historierne på hjemmehjælper feltet, nemlig den om en mægtiggørelse.

\section{EN HISTORIE OM EMPOWERMENT}

Hjemmehjælperfeltets udvikling fra dets genese i 1943 til 1995 kan fortolkes som en diskursiv empowerment for fagets udøvere (og for kvinderne i faget) og som en diskursiv mulig- og mægtiggørelse, idet udviklingen kan tolkes som en anerkendelse af de omsorgsmæssige værdier og omsorgsmæssige kundskaber indenfor denne ekspert diskurs. Der sker en øget italesættelse af omsorgskvalifikationer, der skabes en ny professionel figur og der sker en udvidelse af, hvad der italesættes som kundskaber i den politisk-administrative diskurs. De tre udviklingstendenser vil jeg nu beskrive mere detaljeret.

Der sker en eksplosion i ord, der betegner omsorgskvalifikationer fra 1943 til 1995. Sproget flyder nærmest over med nye betegnende. 9 Den øgede italesættelse kan tolkes som empowerment. Samtidig vil jeg argumentere for, at den politisk-administrative diskurs rummer nogle nye identifikations- og handlings muligheder for personer med kvindeligt (og mandligt) kropstegn i den statsligt finansierede og organiserede omsorg for ældre. Og at diskursen indeholder identifikationer med en professionel status, en anderledes, professionel figur og en udvidet kundskabsbase.

Forskellige billeder konstrueres af den gode hjemmehjælper og hendes/hans omsorgskvalifikationer, og jeg har analyseret udviklingen i italesættelsen af disse kvalifikationer ud fra et professions perspektiv (Dahl, 2000). ${ }^{10}$

I det følgende vil jeg redegøre for hvordan billedet af hjemmehjælpen italesættes i forhold til andre forestillinger ved hjælp af et metodisk greb. Dette greb er en abstrakt figur som den danske psykolog Dorte Marie Søndergaard $(1994,61)$ har introduceret. Med en abstrakt figur søger jeg at kondensere mening i overordnede betydningsstrukturer, der relaterer sig til historiske figurer (Dahl 2000, 17, 136). Jeg vil nu beskrive, hvordan hjemmehjælpen italesættes i forhold til de tidstypiske abstrakte figurer $i$ materialet. Af pragmatiske årsager har jeg valgt at fortælle en forenklet og forkortet version, hvorfor jeg kun henviser til de to tidsmæssige yderpunkter i det følgende, nemlig 1943-54 og 1980-95.11 Udviklingen mellem de to tidsmæssige yderpunkter er ikke lineær, da der også sker tilbageslag i den diskursive kamp (Dahl 2000, 186200). De to yderpunkter er repræsentative for udviklingen, og skaber et overblik, der ikke ville kunne opnås ved at præsentere resultaterne for alle de tre mellemliggende perioder i tidsrummet 1954-1980. 
I perioden 1943-54 er billedet af den dygtige husmoder idealet for husmoderafløseren som profession. ${ }^{12}$ Husmoderen søges videnskabeliggjort i og med, at huslige kompetencer og nogle bestemte menneskelige kompetencer søges formaliseret. ${ }^{13}$ Husmoderen artikuleres som et erhverv og som en stolt kategori. Husmoderafløseren italesættes som havende både betegnede til fælles med den professionelle og husmoderen. Denne periode er karakteriseret ved, at netop de to abstrakte figurer er delvist overlappende. Det ses af nedenstående figur 1, der grafisk viser de to abstrakte figurer og deres relation, samt husmoderafløseren/hjemmehjelpens placering i forhold til dem

1943-1954

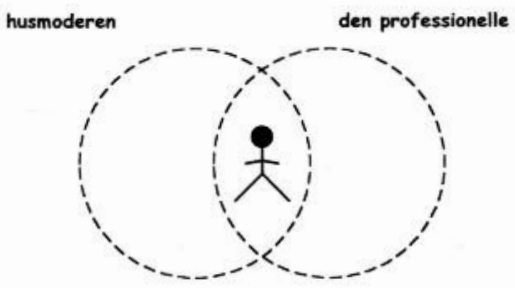

Figur 1

Husmoderen identificeres med betegnede, der ellers associeres med den abstrakte figur for den professionelle. Den abstrakte figur for husmoderen kan beskrives med den betegnede: Empati, erfaring, praktisk håndelag og det, at stå til rådighed. Den professionelle figur kan beskrives med de betegnede: $\mathrm{Vi}^{-}$ den, heltidsbeskæftiget, planlægning, selvstændighed, adgangskrav og faglig ajourføring. Husmoderafløseren ligger mellem de to abstrakte figurer og rummer betegnede fra begge abstrakte figurer (Dahl 2000, 170-172, 291-192). Husmoderafløseren har dermed et ben i hver lejr. Det ses bl.a. af nedenstående citat fra en betænkning:

"I saadanne vanskelige Tilfælde er det af allerstørste Betydning, at Husmoderafløseren med Forstaaelse og Takt søger at vejlede og styrke Husmoderen, saa hun faar Mod til at paatage sig den daglige Husførelse efter overstaaet
Sygdom og Rekreation. Der kan her ydes en god Hjælp med Hensyn til Arbejdets praktiske Tilrettelæggelse, og Husmoderafløseren kan maaske i enkelte Tilfælde blive vejledende for den enkelte Husmoder paa dette Omraade. Det vil være af Værdi for Husmoderafløseren at have en vis psykologisk Indsigt..." (Betænkning om Husmoderafløsere 1947, 33)

'Forstaaelse' og 'Takt' har tvetydige betegnede som empati/dannelse eller professionsetik. Og 'psykologisk Indsigt' kan referere både til et fag eller empati. Jeg kan derfor slutte, at begreberne ofte er indlejret i flere dikotomier: den professionelle versus husmoderen og det emotionelle versus det kognitive. Den delvise overlapning mellem de to abstrakte figurer er interessant, da de professionelle figurer historisk har været defineret i modsætning til husmoderen som abstrakt figur, det vil sige som gensidigt udelukkende figurer (Hänsel 1992).

Jeg vil nu sætte mig ind i tidsmaskinen og rejse til perioden 1980-95, altså et hop på cirka et kvart århundrede (fra 1954).

I perioden 1980-95 er der ikke længere to, men tre abstrakte figurer som hjemmehjælpen artikuleres i forhold til. Der er nemlig både husmoderen, specialisten og den professionelle. Hjemmehjælpens placering ses af nedenstående figur $2 \mathrm{i}$ forhold til de 3 abstrakte figurer, der kan identificeres for perioden 1980-95.

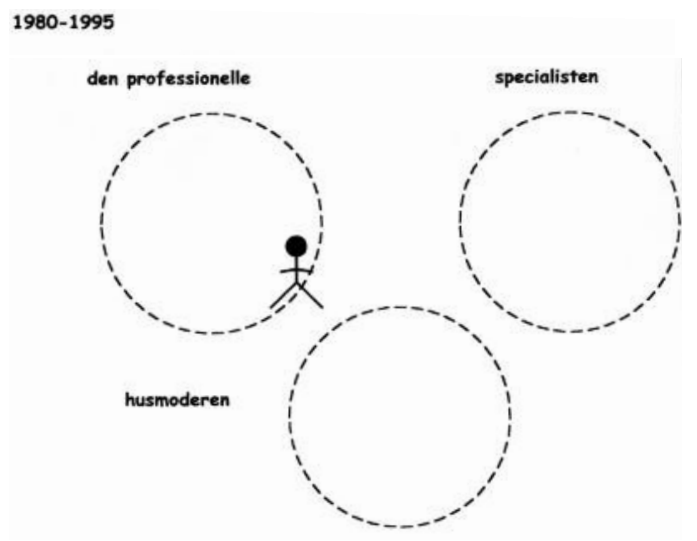

Figur 2 
Opbruddet skyldes, at den oprindelige professionelle figur spaltes i to, nemlig den professionelle som generalist og den professionelle som specialist. Derved introduceres en ny abstrakt figur, nemlig specialisten. Specialisten italesættes som en, der har selvstændighed og fagspecifik viden. Den professionelle forstås i modsætning til specialisten, idet den professionelle figur italesættes med brede kundskaber, mens specialisten som figur forstås som havende snævre, og ikke fleksible kundskaber.

Den professionelle figur associeres med de betegnede: Bred viden/generalist, selvstændighed, helhedssyn og komplicerede opgaver. Hjemmehjælpen italesættes i perioden som identisk med eller på vej ind $\mathrm{i}$ den abstrakte figur for den professionelle. Hjemmehjælpen kan ikke fuldstændigt identificeres med den professionelle figur, da hjemmehjælpen også indeholder elementer af en ikke professionel opfattelse. Men hjemmehjælpens identitet beskrives samtidig via distance til de abstrakte figurer for husmoderen og specialisten. Jeg vil i det følgende kun uddybe de elementer, hvor hjemmehjælpen identificeres med den professionelle figur.

Hjemmehjælpen eller social- og sundhedshjælperen italesættes dermed som en professionel i grænselandet mellem det 'private' og 'offentlige'. Det er en diskursiv mægtiggørelse, da løsrivelsen fra husmoderen (som efter 1943-54 bliver en devalueret kategori) er en forudsætning for tilskrivningen af et professionelt mærkat. Og det mærkat giver status og anerkendelse. Det er et radikalt brud med tidligere tiders associering til det 'private' og 'kvindelige' som værende i modsætning til det professionelle. Dermed overskrives og udfordres nogle stærke dikotomier i den politisk-administrative diskurs.

Samtidig er den nye italesættelse af hjemmehjælpen/social- og sundhedshjælperen epokegørende, da den representerer elementer af en ny type professionel. En slags specialiseret generalist, hvor brede kompe- tencer og helhedsorientering bliver italesat som centrale værdier i diskursen. Disse værdier og kundskaber beskrives i nedenstående citat fra en undervisningsvejledning. I denne vejledning beskrives målet med undervisningen af eleven, nemlig at eleven:

“... udvikler evner til at forstå, vurdere og korrigere egen adfærd, reaktioner og holdninger ... Den obligatoriske praktikopgave i grunduddannelsen: Målet med opgaver er, at eleven: kan redegøre for en af social- og sundhedshjælperens centrale, helhedsorienterede arbejdsopgaver, kan redegøre for de overvejelser og den viden, der belyser de emner eller problemfelter, der ligger til grund for de valgte handlingsforslag i opgaven" (Vejledning om skole- og praktikuddannelsen i de grundlæggende social- og sundhedsuddannelser nr. 223 1990, 1390)

Af citatet ses formuleringen: 'at forstå, vurdere og korrigere egen adfærd, reaktioner og holdninger.' 14 Den viser frem til to centrale betegnede, nemlig: Selvkendskab og selvrefleksion. Social- og sundhedshjælperen (eleven) italesættes som reflekterende over hvilke generelle kundskaber, der kan anvendes overfor en borger. Og eleven som begrundende sin beslutning. Og samtidig italesættes social- og sundhedshjælperen som havende behov for at kende sig selv for at undgå uhensigtmæssigt reaktionsmønstre eller holdninger. Hvis de betegnede kondenseres, peger de hen mod en ny abstrakt figur, nemlig den profesionelle som generalist - en generalist med 'helhedsorienterede arbejdsopgaver'. Sammenfattende kan den professionelle figur karakteriseres med det som jeg har kaldt de 3 S'er: Selvstendighed, selvkendskab og selvrefleksion.

Dermed skabes en ny form for professionel identitet. En position i diskursen, hvor omsorgskvalifikationer afkønnes, idet de bliver løsrevet fra den abstrakte figur for husmoderen (Dahl 2000, 227-229, 293294). Dermed genereres et fag med en selvstændig kundskabsbase. Kundskabsba- 

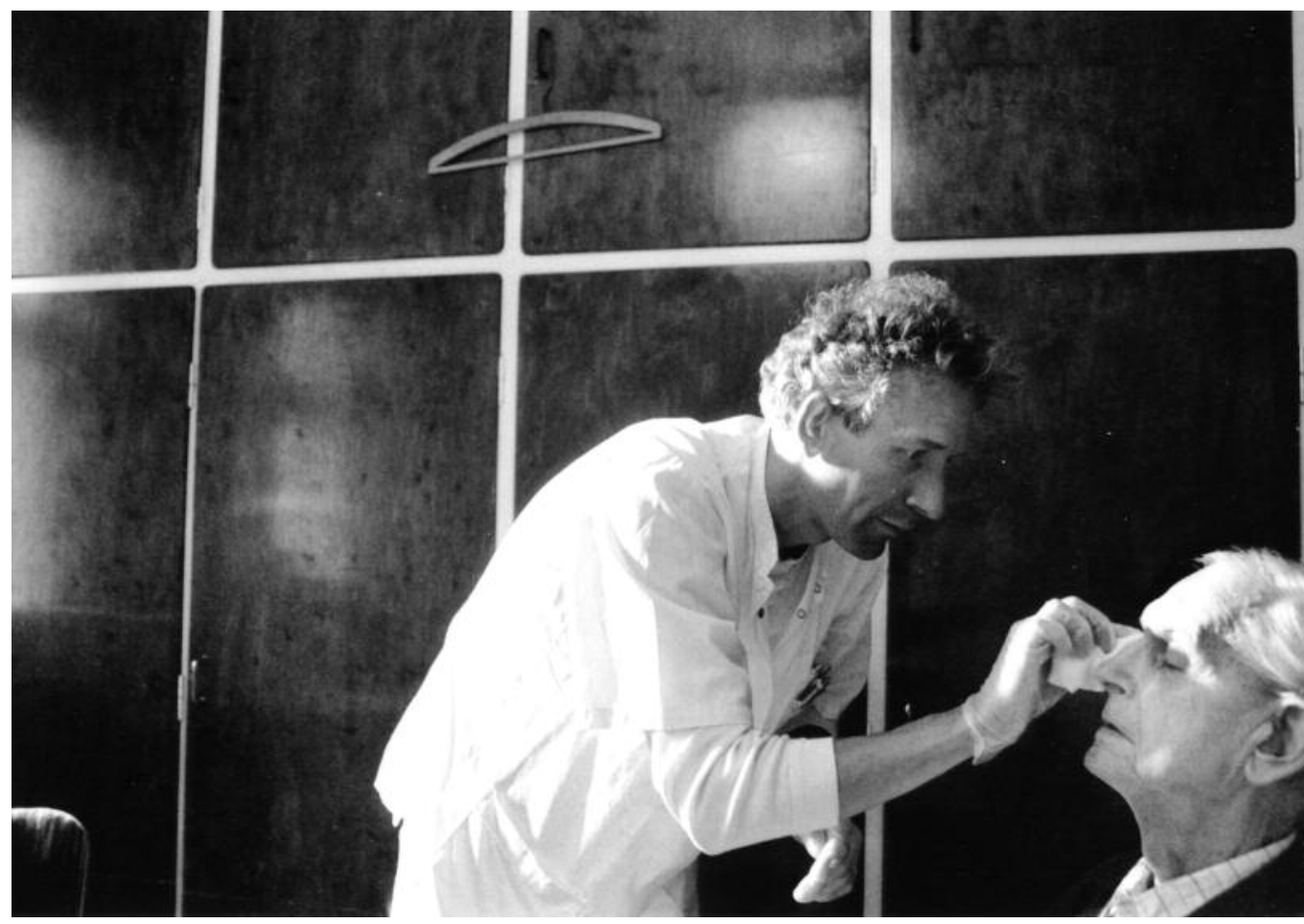

Hjemmesygepleje iKobenhavn. Foto: Nicolai Howalt, BAM

sen italesættes som værende bred, men bliver ikke beskrevet som så bred, at en professionsdiskurs bliver umulig. 15

Denne nye type professionelle med bredere kompetencer og en bredere kundskabsbase kan, potentielt set, på det diskursive felt bidrage til at destabilisere italesættelsen af de mere traditionelle, eksklusive professioner som læger eller advokater. Italesættelsen af social- og sundhedshjelperen udfordrer indirekte den hidtidige teoretiske opfattelse af professioner ved at artikulere elementer af andre kundskabsbaser relateret til krop og følelser (Dahl 2000, 297-300 og Dahl (under udgivelse)). Den potentielle destabilisering af den traditionelle, teoretiske opfattelse ses af reartikulationen af den professionelle figur, der potentielt set ændrer magtrelationen mellem hvad, der giver anerkendelse og status på et givet felt. På hjemmehjælper feltet udvides og reorganiseres den politisk-administrative diskurs. Kriterierne for empowerment er opfyldt, da der både sker en øget italesættelse og en artikulation af både en professiondiskurs og en bredere kundskabsbase. Men italesættelsen af en bredere kundskabsbase kan også tolkes i et andet perspektiv, nemlig som en disempowerment.

\section{EN ANDEN HISTORIE OM DISEMPOWERMENT}

Italesættelsen af en bredere kundskabsbase og et øget fokus på Selvet i perioden 194395 kan også tolkes som en øget og mere subtil styring af denne type offentligt ansatte omsorgsudøvere, der som nævnt hovedsagelig er kvinder. Med en øget og mere subtil styring af følelser, kroppen og Selv' et. I det følgende vil jeg især fokusere på perioden 1972-1995, selvom jeg også vil referere til perioder før 1972.

Denne anden tolkning af den diskursive udvikling kan ses som et eksempel på Foucault's tese om en generel transformation af 
magt og dens former. Denne udvikling kan også beskrives med et begreb for en særlig moderne magtform, nemlig det som Foucault benævner 'bio-magt'. Denne magtform underlægger sig kroppen og søger at kontrollere befolkningen. I bio-magten indgår: "...life and its mechanisms into the realm of explicit calculation and made knowledge-power an agent of transformation of human life" (Foucault 1978, 143).

Denne nye magt søger bl.a. at disciplinere kroppen, dens udtryk og at gøre befolkningens sundhed, lykke og liv til et reguleringsobjekt. Denne magtform har den danske sociolog Karen Sjørup beskrevet som: "...magten over "det sociale", over de mellem-menneskelige forhold, som idag i høj grad formidles af staten gennem videnskabelige diskurser og praksisser for omsorg, pleje, behandling af syge, uddannelse og opdragelse" (Sjørup 1997, 10). Bio-magten kan bl.a. identificeres på det diskursive felt for hjemmehjælp. En indikator på biomagten findes bl.a. i den diskurs som jeg har benævnt en ledelses- og udviklingsdiskurs. Denne diskurs indeholder to grupper af nye begreber. En gruppe, der vedrører en ny ledelsesforståelse, og en anden gruppe, der henter begreber fra en analogi til markedet. Den nye ledelsesforståelse fokuserer på ledelse både af andre og af en selv, og på konstant udvikling som medarbejderens eget ansvar. Udvikling er så dominerende, at det bliver selvrefererende - udvikling er godt, da udvikling er godt! Udvikling ses som en mulighed og en forpligtelse i forlængelse af den ledelses- og udviklingsorienterede diskurs. Forpligtelsen kommer bedst til udtryk i formuleringen: 'lære at udvikle sig via sit arbejde', der er typisk for perioden 1980-95. Det vil sige som en forpligtelse, der skal tilegnes via en ændret holdning til arbejdet. ${ }^{16}$

I diskursens selvforståelse må social- og sundhedshjælperen spørge sig selv om betydningen af sin personlighed (og tidligere erfaringer) i relationen til de ældre, der skal hjælpes. Det ses i en undervisningsvejled- ning for nyansatte hjemmehjelpere med spørgsmålet: 'Hvordan er man selv?' Det spørgsmål henviser bredt til, hvad der kunne kaldes det personlige i det faglige. Spørgsmålet indgår i en række spørgsmål til eleven, der sigter på at sætte en reflektionsproces i gang om ens og andres personligheder:

"Hvordan er de mennesker, hjemmehjælpen kommer til? Hvordan er man selv? Hvad vil det sige at være gammel - hvordan forholder man sig til sin egen alderdom? Hvordan passer egne erfaringer til de arbejdsopgaver, der stilles?" (Undervisningsvejledning, Introduktion af nyansatte hjemmehjelpere 1980, 16)

Så det personlige, Selvet og selvansvarliggørelse er i fokus med den ledelses- og udviklingsmæssige diskurs. Men hvorvidt er det en ny udvikling, at Selvet er i fokus? Der kan svares både be- og afkræftende på spørgsmålet. På det diskursive felt har Selvet også været italesat tidligere, allerede i perioden 1943-54. Bare med andre ord som 'egnethed' eller senere med ord som 'personlig egnethed', 'modenhed' og 'personlig erfaring'. Det bemærkelsesværdige i forhold til tidligere er, at der er sket en øget italesættelse. Der er flere ord der henviser til denne betegnede. Teksterne flyder over med referencer til det personlige og til Selvet. Desuden er der en anden forskel, nemlig at kroppen i større omfang inddrages i teksterne. Det ses bl.a. af følgende beskrivelse af den rigtige adfærd for hjemmehjælpere $\mathrm{i}$ forbindelse med colostomi patienter i hjemmet:

“Hjemmehjælpen kan hjælpe med at: give klienten lejlighed til at tale om sin colostomi. Vise en naturlig, positiv holdning (husk at ansigtsudtryk og bevægelser kan røbe lige så meget som ord)" (Undervisningsvejledning for overgangskursus for hjemmehjælpere $1977,31)^{17}$

Her skabes et normativt ideal for hjemmehjælpens adfærd, der handler om at discipli- 
nere Selvet, så kropslige udtryk som overraskelse og afsky forhindres. Reaktioner, der er tegn på, at et tabu indenfor vores vestlige civilisation brydes, nemlig omkring kroppens emissioner. Denne italesættelse udtrykker en 'naturlig' adfærd som ønskelig, men den ønskede adfærd er netop italesat, styret og reguleret. Men hvorfor tolke det som disempowering, når kroppen og Selvet italesættes?

Den øgede politiske styring involverer en moralisering og normalisering af subjektet. Et bestemt ideal for hvilke kvalifikationer og adfærd, der artikuleres som nyttige og nødvendige. Denne mere intensive styring af hjemmehjælpere/ social-og sundhedshjælpere rammer hovedsageligt personer med kvindeligt kropstegn, da størsteparten af hjemmehjælperne/social- og sundhedshjælperne er kvinder.

Derfor er jeg af den opfattelse, at Karen Sjørups påstand om, at: “...kvinder efterhånden har tilkæmpet sig en anseelig del af den bio-politiske diskursmagt....der handler om magten over 'det sociale' “ (Sjørup 1997, 10) må modificeres. Det er muligt, at nogle kvinder har tilegnet sig denne biomagt og kan reartikulere den. Men der må differentieres mellem forskellige grupper af kvinder og deres relation til bio-magten. Der eksisterer andre grupper af kvinder, der ikke er så priviligerede og har mere begrænsede muligheder for at modsætte sig biomagten og de forskellige diskurser, som den er indeholdt i. Grupper som hjemmehjælpere og social-og sundhedshjælpere. De er hovedsagelig modtagere af denne nye magtform og af en af bio-magtens representanter, nemlig som nævnt tidligere, ledelses- og udviklingsdiskursen.

\section{AfsLuTNING}

Jeg har beskrevet, hvordan et policy-felt for omsorgsmæssige kvalifikationer udvikles og konsolideres i perioden 1943-95. Den særlige italesættelse på feltet kan både ses som udtryk for empowerment og disempow- erment. Der er mulig- og mægtiggørende elementer i den øgede italesættelse af omsorgsmæssige kvalifikationer, den identificerede professionsdiskurs på feltet og udvidelsen af hvad, der beskrives som omsorgsmæssige kundskaber. Omvendt kan den selvsamme udvikling også tolkes som et tilbageslag, hvis den ses som udtryk for en bio-magt, der skaber en polarisering mellem kvinder. Nemlig mellem de kvinder, der forvalter bio-magten og er med til at udforme ekspert diskursen om hjemmehjælperens/social- og sundhedshjælpens kvalifikationer og de kvinder som eksempelvis hjemmehjælpere/social- og sundhedshjælpere både forvalter og selv er underlagt bio-magten.

De to historier er ligeværdige, da de fortæller hvert sit aspekt af feltets udvikling. Historierne handler om ambivalensen for omsorgsudøvere med kvindeligt kropstegn i konsekvenserne af udviklingen af 'magtens sprog'. En ambivalens, der vedrører nye muligheder og begrænsninger i diskursens forestillingshorisont, og som også kunne beskrives som et dilemma for feminister. Et dilemma, der handler om et umuligt valg mellem enten en øget politisk synlighed og styring, eller alternativt en tavshed og dermed usynlighed. Et valg mellem pest og kolera.

Mulighederne i diskursen handler om synliggørelse som et resultat af en stigende italesættelse på feltet, det vil sige, relationen mellem det 'sigelige' og 'synlige'.18 Og muligheder, der handler om anerkendelse af hjemmehjælpens professionalisme og respekt om omsorgsarbejdet i 'magtens sprog'. Det negative i udviklingen for hjemmehjælpere/social- og sundhedshjælpere er, at den øgede italesættelse også rummer nye muligheder for styring, der går tættere på omsorgsudøvernes Selv forstået som det kognitive, emotionelle og kropslige. Dette mere indgribende ideal for den gode hjemmehjælper/ social- og sundhedshjælper er det negative aspekt af en øget politisk-administrativ synlighed for den del af omsorgspolitikken. 


\section{NOTER}

1. Jeg vil definere italesættelse som en sætten-i-tale, det vil sige at 'noget' frembringes og bliver til som et socialt og sprogligt faktum (Andersen 1997, 15). Jeg anvender 'artikulation' og 'konstruktion' som synonymer for italesættelse.

2. Jeg anvender en bredere opfattelse af 'omsorgspolitik' (Oprindelig: 'care politics') end Skjeie. Det skyldes, at jeg ikke begrænser omsorgspolitik til 'omsorgs- og karriere politik' og omsorg i familiemæssigt regi, men også inddrager den betalte omsorg for ældre i eget hjem.

3 . Blandt de skandinaviske kvinde-og kønsforskere har der i nogen tid udfoldet sig en debat mellem henholdsvis optimister og pessimister omkring fortolkningen af udviklingen i de skandinaviske velfærdsstater (Bergquist 1999, 7; Wägnerud 1998, 46-47). Skjeie argumenterer for, at de to positioner blot handler om forskellige prioriteringen inden skandinavisk kønsforskning, nemlig henholdsvis en værdighedsforskning og en magtkritik (Skjeie 1999, 100). Jeg er enig med Skjeie. Forskellene mellem værdighedsforskningen (den optimistiske pol) og magtkritikken (den pessimistiske pol) har været overvurderet. Det betyder, at empowerment og disempowerment i nogle tilfælde kan ses som forskellige aspekter af en udvikling.

4. Social- og sundhedshjælpen er et nyt begreb, der blev introduceret sammen med de nye etårige uddannelser i begyndelsen af 1990'erne. Hjemmehjælpen har som felt været forsømt, mens der har været nogle undersøgelser ud fra et bruger perspektiv (Plattz 1987 og Platz 1989-90). Den danske sociolog Myra Lewinter har for nylig udgivet: Spreading the Burden of Gratitude 1999, der beskæftiger sig både med et bruger og et udøver perspektiv (inddragende både den formelle og uformelle omsorg).

5. For en nærmere afklaring af det analytiske søgelys 'omsorg', der er anvendt, se min afhandling (Dahl 2000, 18, 81-91). Kort fortalt, er omsorg en særlig slags arbejde, der udføres overfor ikke selvhjulpne individer, der rækker ud over den spontane omsorg (Wærness 1982, 12).

6. Felt begrebet refererer her til et diskursivt felt, hvor diskurser indgår i en sammenhæng, kæmper om magten og afgrænser sig i forhold til det udenfor. Jeg har analyseret feltets afgræsning, og identificeret kontinuitet og brud i feltet. Dermed har jeg kortlagt feltet.

7. Denne formulering refererer til, som allerede nævnt, at ca. 90-95\% af hjemmehjælpere/socialog sundhedshjælpere i dag er kvinder. Begrebet 'kvindeligt kropstegn' stammer fra den danske psykolog Dorte Marie Søndergaard (1996).
8. Det skal præciseres, at jeg ikke sigter på, at diskutere spørgsmålet om gyldighed i en videnskabsteoretisk forstand. Det har jeg gjort andetsteds (Dahl 2000, 56-59).

9. Jeg vil definere en betegnede som 'begrebet', det vil sige billedet af tingen og ikke tingen i sig selv (Dahl 2000, 132 og Saussure 1990, 67). Den betegnende referer derimod til den anden del af tegnet, nemlig lyden af ordet. Dermed består tegnet som sprogets meningsskabende enhed af både en betegnet (billedet af tingen) og en betegnende (lyden).

10. Dermed forstår jeg en analyse af, hvordan der skabes en dominerende forestilling om en særlig viden som knyttet til en bestemt form for arbejde, og skabelsen af en forestilling om dets hensigtsmæssige overgang fra ubetalt til betalt arbejde (Dahl 2000, 13).

11. Hvis læseren skulle ønske en længere version kan jeg henvise til opsummeringen i min afhandling (Dahl 2000, 290-296) og til artiklen: "Husmoderen, hjemmehjælpen og den professionelle" (Dahl 1999). Perioden 1943-95 har jeg opdelt i fem forskellige perioder: 1943-54, 1954-68, 1968-72, 1972-80 og 1980-95. For de generelle principper bag de valgte periodiseringer, se venligst min afhandling (Dahl 2000, 140-142).

12. Husmoderafløseren opfattes ofte som forløber for hjemmehjæelpen, men husmoderafløseren skal i stedet ses som en slags hjemmehjxlper, da hendes arbejdsopgaver også blev italesat som rettet mod xldre i eget hjem (Dahl 2000, 181). Husmoderafløseren har nemlig delvist samme betegnede som hjemmehjælpen, men 'hjemmehjælp' som begreb først anvendes fra 1958 (Dahl 2000, 187).

13. De to idéhistorikere Lars-Henrik Schmidt og Jens Erik Kristensen tolker denne udvikling i bogen: Lys, luft og renlighed (1986) udelukkende negativt ud fra et kvindeperspektiv. Dels som en naturalisering af kvinden, dels som en kolonialisering af hjemmet med en videnskabelig logik. Jeg er enig i, at 'kvinden' biologiseres og dermed naturaliseres $\mathrm{i}$ den pågxldende periode. Men jeg er uenig i deres tolkning af denne udvikling og af deres identifikation af en snæver kundskabsopfattelse (Dahl 2000, 168-169).

14. Citaterne fra de to perioder $1943-54$ og 198095 stammer fra to forskellige slags materiale i den politisk-administrative diskurs, nemlig henholdsvis en betænkning og en undervisningsvejledning. Udviklingen fra betænkninger til undervisningsvejledninger skal ses som symptomatiske for en generel udvikling i materialets karakter, nemlig hen imod en større detalje regulering.

15. Lars-Henrik Schmidt opstiller i et interview to 
mulige strategier for en professionalisering, der har karakter af at være et dilemma (Jensen 1998).

16. En generel gennemgang af hvorledes der skabes en videnskabelig ledelsesdiskurs og dens udvikling fra bl.a. 'ansat' til 'medarbejder' beskrives af den danske idéhistoriker Bettina Mogensen (1999). 17. Colostomi er et anlæg, hvor afføring fra tyktarmen føres ud gennem bugvæggen.

18. Denne sondring mellem det 'sigelige' og det 'synlige' har jeg fra Lars-Henrik Schmidt (1993).

\section{LITTERATUR}

- Andersen, Niels Åkerstrøm (1997): Udlicitering

- Strategi og historie. København: Nyt fra sam-

fundsvidenskaberne.

- Bergqvist (1999): "Norden - en modell eller flera?", i Christina Bergqvist m.fl.(red.) Likestilte demokratier? Universitetsforlaget, Oslo.

- Dahl, Hanne Marlene (1999): "Husmoderen, hjemmehjælpen og den professionelle", i Social kritik 1999/63.

- Dahl, Hanne Marlene (under udgivelse): "Professionalisering i hjemmet? Kampen om hjemmehjælpens professionalisering", i Kirsten Lomborg og Else S. Nielsen (red.) På arbejde i hjemmet. Gyldendal, København.

- Dahl, Hanne Marlene (2000): Fra kitler til eget tøj-Diskurser om professionalisme, omsorg og køn. Politica, Århus.

- Dahl, Hanne Marlene (1994): "Nyere patriarkatsteori - Som en fugl uden vinger? Teorier om patriarkatet”, i Anna G. Jónasdóttir og Gunnela Björk (red.) Högskolan i Örebro. Örebro.

- Ferguson, Kathy (1987): "Male-ordered Politics: Feminism and Political Science", in T. Ball (red.) Idioms of Inquiry - Critique and Renewal in Political Science. New York University Press, Albany. - Foucault, Michel (1978): The History of Sexuality. Penguin, London.

. Fraser, Nancy (1997): Justice Interruptus. Routhledge, London.

- Giddens, Anthony (1979): Central Problems in Social Theory. Macmillan, London.

. Hänsel, Dagmar (1992): "Wer ist der Professionelle?”, in Zeitschrift für Pädagogik årg. 38, nr. 6. - Jensen, Vibeke Bye (1998): "Pædagoger bliver familiens tyende", i Børn \& unge 1998/1-2, 8-10. - Knudsen, Anne (1990): "Tavshed er magtens Tegn" i Linda Andersen (red.) Livsmagt - nye perspektiver på kultur, magt og køn. Århus Universitetsforlag.
- Laclau, Ernesto og Chantal Mouffe (1985): Hegemony and Socialist Strategy. Verso, London.

- Lewinter, Myra (1999): Spreading the Burden og Gratitude. Sociologisk Institut, København.

- Mogensen, Bettina (1999): "Inderliggørelsen af ledelsespraktikkerne”, i GR US 1999/59.

- Platz, Merete (1997): Langst mulig I eget hjem.

Socialforskningsinstituttet, København.

- Platz, Merete (1989-2000): Gamle i eget hjem.

Socialforskningsinstituttet, København.

- Saussure, Ferdinand de (1990): Course in General Linguistics. Duckworth, London.

- Schmidt, Lars-Henrik og Kristensen, Jens Erik (1986): Lys, luft og renlighed - Den moderne socialbygiejnes fødsel. Akademisk Forlag, København.

. Schmidt, Lars-Henrik (1993): "Grænseløshedens tyranni”, i Agrippa 1993/14.

- Sjørup, Karen (1997): "Velfærdsstaten som middel i kvinders magtspil - governmentalitet og statsfeminisme i den moderne velfærdsstat", i Kvinder, Køn \& Forskning 1997/2.

- Skjeie, Hege (1992): Den politiske betydningen av kjønn. Institut for samfunnsforskning, Oslo.

- Skjeie, Hege (1999): "Likestillingsprocesser og kjønnsmakt”, i Øyvind Østerud m.fl. (red.) Mot en ny maktutredning. Ad Notam Gyldendal, Oslo. . Søndergaard, Dorte Marie (1994): "Køn i formidlingsproces mellem kultur og individ: nogle analytiske greb", i Psyke \& Logos 1994/15.

- Søndergaard, Dorte Marie (1996): Tegnet på kroppen. Museum Tusculanums Forlag, København. - Wägnerud, Lene (1998): Politikens andra sida. Göteborg Studies in Politics, Göteborg. - Wrrness, Kari (1982): Kvinneperspektiver på Socialpolitikken. Universitetsforlaget, Oslo.

\section{SUMMARY}

This article concerns home-helpers and the construction of a political-administrative field in Denmark for discussion of their qualifications. The investigation covers the period 1943-95. Two interpretations of the articulation are juxtaposed and discussed in relation to the concepts of empowerment and disempowerment. It is concluded that the discoursive development poses a dilemma for feminists.

Hanne Marlene Dahl, Ph.d., cand.scient.pol. et exam.art, MA. Adjunkt ved Institut for samfundsvidenskab og erhvervsøkonomi, Roskilde Universitetscenter 